\title{
Anatomi leher dan kondisi patologisnya: Pemeriksaan USG
}

\author{
Lusi Epsilawati* ${ }^{*}$ iD, Azhari', Norlaila Sarifah²
}

\begin{abstract}
Objectives: This study is aimed to introduce an its characteristics. Ultrasound can thoroughly assess overview of the anatomy of the neck region as well pathological conditions related to anatomy. as an overview of some pathological conditions that can be seen through Ultrasound.

Literature Review: There was a characteristic in the anatomy of the neck by Ultrasound. Anatomy of the neck on Ultrasound, divided into several areas with

Conclusion: Ultrasound was a modality that can be used to see the condition of the anatomy, including the neck area. Pathological conditions were also able to be appropriately seen through Ultrasound.
\end{abstract}

Keywords: Ultrasound, the anatomy of the neck, pathological image

Cite this article: Epsilawati L, Azhari, Sarifah N. Anatomi leher dan kondisi patologisnya: Pemeriksaan USG. Jurnal Radiologi Dentomaksilofasial Indonesia 2020;4(2)47-54. https://doi.org/10.32793/jrdi.v4i2.549

${ }^{1}$ Departemen Radiologi Kedokteran Gigi, Fakultas Kedokteran Gigi, Universitas Padjadjaran, Bandung, Indonesia 40132

${ }^{2}$ PPDGS Radiologi Kedokteran Gigi, Fakultas Kedokteran Gigi, Universitas Padjadjaran, Bandung, Indonesia 40132

\section{*Correspondence to:}

Lusi Epsilawati

凶lusifkg92@gmail.com

Received on: June 2020

Revised on: July 2020

Accepted on: August 2020

\section{PENDAHULUAN}

Ultrasound atau ultrasonografi (USG) dengan jangkauan probe. Getaran inilah yang merupakan suatu modalitas di bidang radiologi nantinya menggambaran ketebalan, tinggi dan yang memanfaatkan gelombang frekuensi suara di keadaan jaringan yang sedang dilihat. ${ }^{2}$

atas 20.000 Hertz $(\mathrm{Hz})$, gelombang tersebut di atas jangkauan pendengaran manusia sekitar 1-30 megahertz $(\mathrm{MHz})$ dalam USG diagnostik. Pencitraan ultrasound diagnostik bergantung pada analisis komputerisasi. Gelombang ultrasonik yang dihasilkan secara non-invasif membangun citra halus internal struktur tubuh yang diperoleh dari panjang gelombang yang saling bertolak belakang dengan frekuensi. Artinya semakin panjang suatu gelombang maka frekuensi yang dihasilkan akan semakin pendek begitu juga sebaliknya. Dalam kondisi frekuensi tinggi dan panjang gelombang pendek mudah terjadi atenuasi (kehilangan kekuatan sinyal) pada jaringan. Untuk mengatasi hal ini maka diperlukan rentang frekuensi yang berbeda untuk setiap jaringan, dan frekuensi yang sering kali digunakan untuk pencitraan bagian tubuh berkisar: 3-5 $\mathrm{MHz}$ untuk daerah perut, 5-10 MHz untuk bagian kecil (dangkal), dan 10-30 $\mathrm{MHz}$ untuk kulit atau mata. ${ }^{1}$

Untuk menyalurkan getaran suara maka diperlukan suatu penghantar yang dikenal dengan nama probe dan media yang mentansfernya yaitu cairan kristal piezoelektrik (transduser). Getaran akustik (echo) yang diterima oleh probe bukan saja getaran yang sifatnya tegak lurus dari arah datangnya getaran awal, akan tetapi getaran lainnya yang membentuk sudut terhadap jaringan yang sedang divisualisasikan harus disesuaikan
Semakin banyak jaringan yang diperiksa maka akan semakin banyak echo yang diterima. Kondisi permukaan jaringan yang tidak halus dapat mengganggu getaran akustik yang akan diterima oleh scanner, semakin tidak rata maka semakin bervariasi getaran yang diterima. Kondisi ini sering disalahartikan sehingga sering dikatakan sebagai gangguan, tapi kondisi ini dapat dikurangi dengan semakin seringnya seseorang dalam mengoperasionalkan USG. ${ }^{2}$

\section{STUDI PUSTAKA}

Ultrasonografi (USG) adalah salah satu modaliti yang sering digunakan dalam pencitraan. USG merupakan alat pencitraan yang memberikan gambaran secara real time. Pencitraan USG sangat bergantung pada peralatan penghantar yang dikenal dengan probe serta cairan transduser (Kristal piezoelektrik). Kristal piezoelektrik mengubah tegangan listrik di permukaannya. Sebaliknya tegangan diterima pada sisi berlawanan dari piezoelektrik, menyebabkan perubahan ketebalannya (piezoelektrik tidak langsung atau timbal balik efek). ${ }^{1}$ Jika tegangan listrik yang diaplikasikan bergantian, maka akan terjadi transmisi gelombang suara ke media sekitarnya. Kristal piezoelektrik berfungsi sebagai transduser, 
yang mengubah energi listrik menjadi energi mekanik dan sebaliknya. Seperti yang terjadi di air, ultrasound merambat di jaringan lunak berupa gelombang longitudinal, dengan kecepatan ratarata sekitar $1540 \mathrm{~m} / \mathrm{s}$ (jaringan lemak, $1470 \mathrm{~m} / \mathrm{s}$; otot, $1570 \mathrm{~m} / \mathrm{s}$ ). Susunan gambar dengan ultrasound didasarkan pada pengukuran jarak yang bergantung pada kecepatan propagasi yang konstan. Pencitraan pada tulang dengan daya tembus $3600 \mathrm{~m} / \mathrm{s}$ dan tulang rawan, sering kali memberikan efek yang buruk pada gambar yang dihasilkan, gambaran inilah yang dikatakan sebagai artefak. $^{1} \quad$ Panjang gelombang ultrasound mempengaruhi resolusi gambar, semakin tinggi frekuensinya, semakin pendek panjang gelombang maka semakin baik resolusinya. Tulang menyerap ultrasound lebih banyak daripada jaringan lunak, sehingga pada umumnya ultrasound cocok untuk memeriksa hanya permukaan tulang. Energi ultrasound tidak bisa mencapai terdalam dari tulang. Gambar ultrasound seringkali menunjukkan zona hitam di balik tulang, inilah yang dikenal sebagai bayangan akustik, dan terlihat apabila frekuensi yang digunakan tidak terlalu rendah. ${ }^{1}$
Selain percitraan yang biasa dilakukan ultrasound memiliki kemampuan untuk memberikan gambaran berbeda dengan efek Doppler. Efek Doppler pada awalnya diperkenalkan oleh ilmuwan Austria Christian Doppler. Efeknya mampu memberikan perubahan dalam frekuensi gelombang yang dipancarkan oleh benda bergerak seperti yang terdeteksi. Doppler mampu memvisualisasikan dengan tambahan warna yang dihasilkan akibat perbedaan frekuensi yang dihasilkan. ${ }^{3}$

Teknik baru yang sedang dikembangkan adalah teknik panoramic-scan. Gambaran ini menggunaan prosesor gambar berkecepatan tinggi dimana beberapa gambar real-time dibuat dalam satu gambar besar (panorama) dari seluruh wilayah tubuh tanpa kehilangan informasi, akan tetapi gambarannya menjadi tidak real time lagi. Dalam penggunaannya, ultrasound sering kali membutuhkan agen kontras. Agen kontras dapat memberikan gambaran berbeda dengan doppler yang berfungsi pada media yang bergerak, agen kontras mampu memvisualisasikan pada jaringan atau organ tidak bergerak. ${ }^{1}$

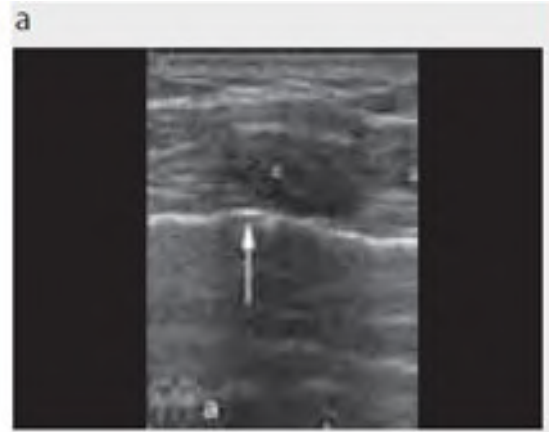

b

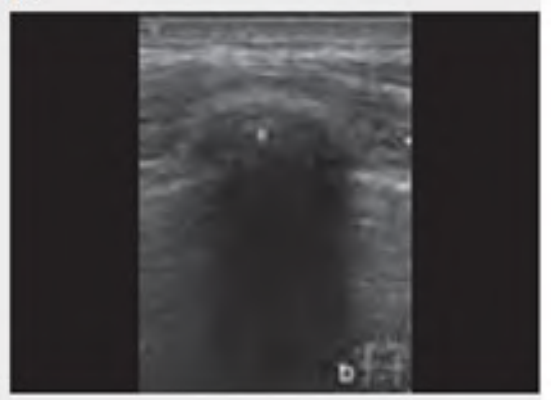

Gambar 1. Gambaran dari pembuluh darah di pleura (anak panah) yang berada pada dorsal cartilago, gambaran ini mencoba memvisualisasikan jaringan dan tulang dan area b dikatakan sebagai acustic shadow ${ }^{3}$

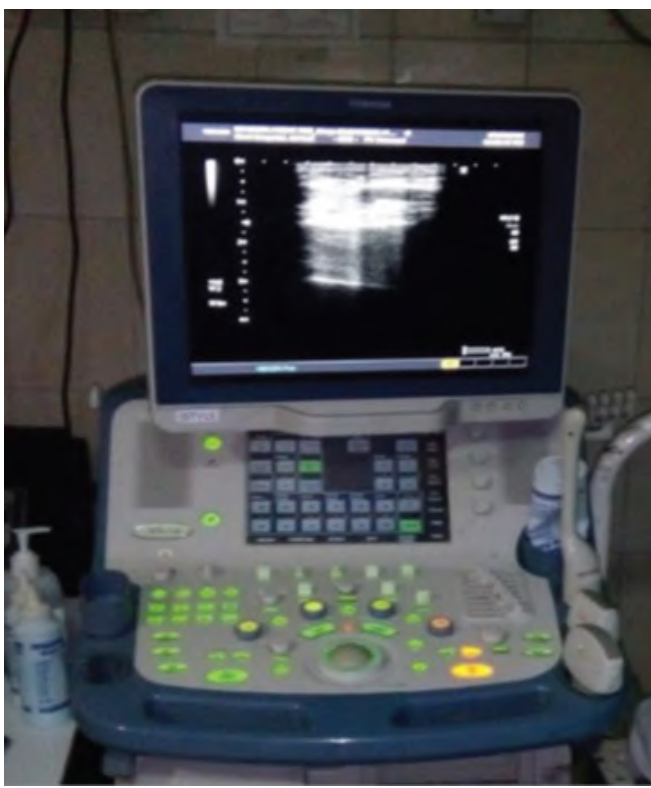

Gambar 2. Modalitas USG 

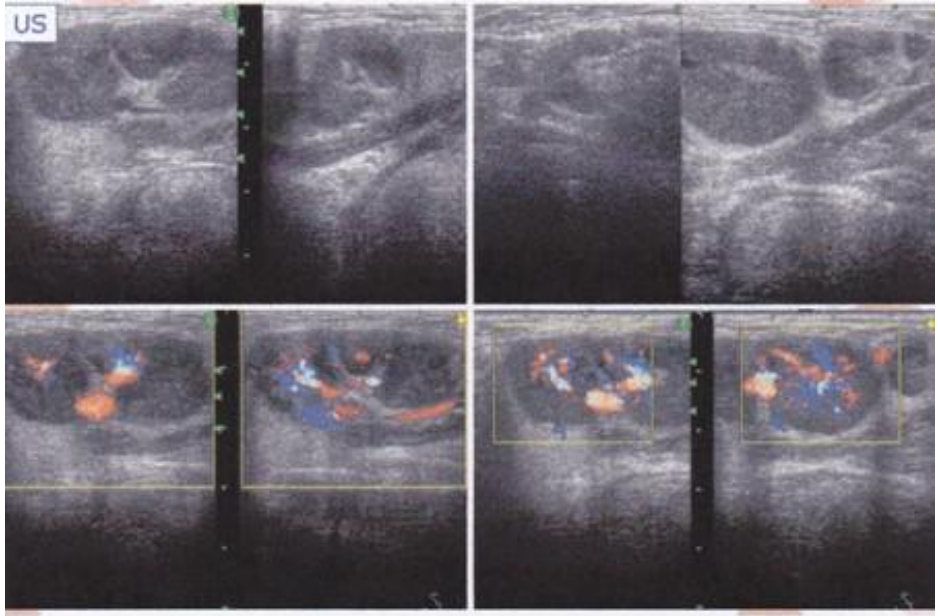

Gambar 3. Memperlihatkan adanya pewarnaan pada objek yang bergerak yang dikenal sebagai efek doppler ${ }^{4}$
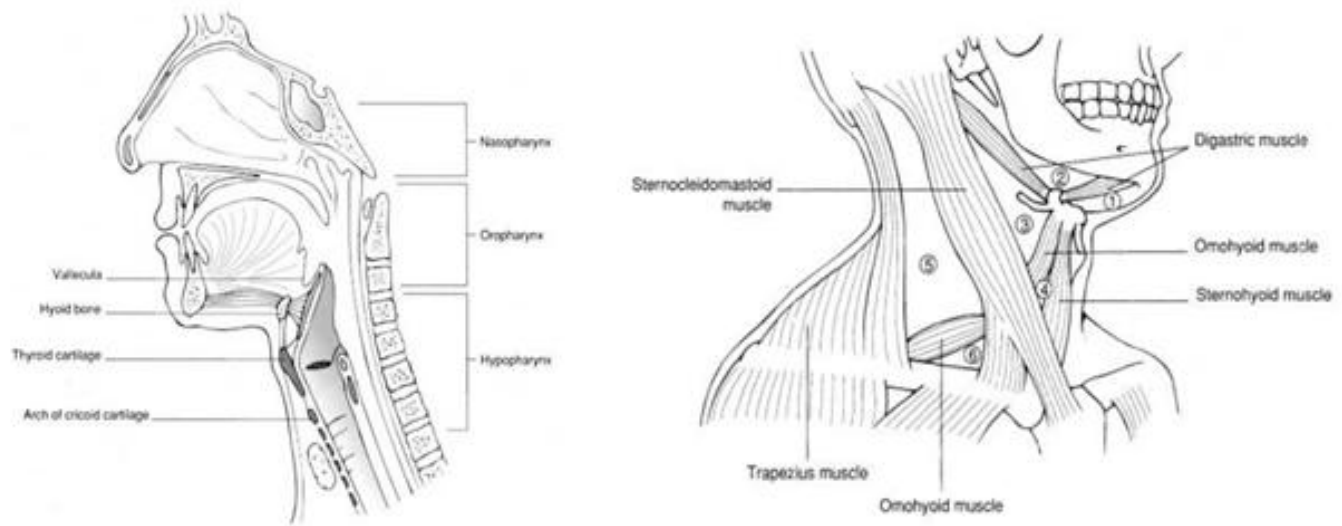

Gambar 4. (A). Wilayah leher dan kepala yang terbagi menjadi 3 area yaitu : nasopharing, oropharing dan hypopharing. (B). Terlihat potongan Triangle Muscle : sternocleidomastoideus, triangle posterior, triangle occipital dan supraclavicula ${ }^{3}$

\section{DISKUSI}

Penggunaan ultrasonografi lebih diutamakan pada jaringan lunak. Pada daerah kepala dan leher, terdapat beberapa jaringan yang meliputi jaringan lunak seperti otot, kelenjar ludah, limfatik, endokrin, nervus, dan struktur vaskular. Hampir semua jaringan lunak ini dapat dibaca pada USG. Pada pembahasan kali ini yang akan diuraikan adalah gambaran otot. Gambaran otot yang akan dibahas meliputi kondisi normal dan patologis yang umum terjadi. $^{2}$

\section{GAMBARAN OTOT LEHER DAN KEPALA PADA ULTRASONOGRAFI}

Anatomi otot pada daerah leher dan kepala dapat dibagi dalam tiga kelompok besar: Nasopharinx, Oropharinx dan Hypopharinx, sedangkan tulang yang terlibat adalah tulang vesicula, hyoid bone, thiroid bone dan cricoid bone. Otot-otot yang ada didaerah tersebut diantaranya adalah sternocleidomastoid, digastricus dan omohyoid. Otot strenocleidomastoid merupakan otot mastoid yang berjalan menuju clavicula dan sternum membatas dua triange anterior dan posterior. Triangle anterior terdiri dari anterior strenocleidomastoid, supra hyoid yang terdiri dari otot digastrik, submental dan submandibular serta infra hyoid yang terdiri dari omohyoid, digastricus sampai ke carotid triangle. Triangle posterior terdiri dari post strenocleidomastoid dan anterior trapezium, occipital dan supraclavicula. ${ }^{3}$

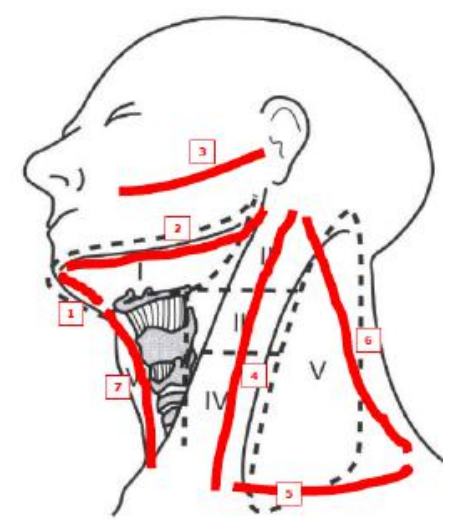

Gambar 5. Pembagian daerah leher dan kepala : (1) Submental;

(2) Submandibula; (3) Parotis; (4) Deep cervical chain; (5) Tranverse cervical ${ }^{2}$ 

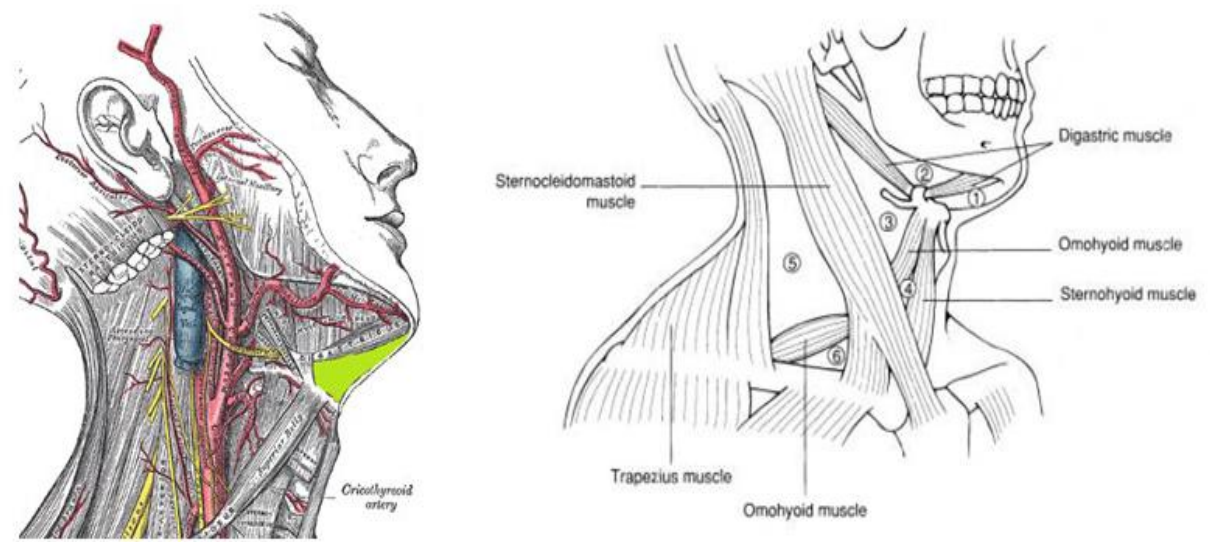

Gambar 6. Anatomi submental area. Terlihat otot digastrikus, mylohyoid ${ }^{4,5}$

Gambaran anatomi dari bagian leher dan kepala dijabarkan sebagai berikut:

\section{Daerah Submental}

Ruang submental adalah ruang fasia kepala dan leher (terkadang juga disebut ruang fasia). Ini adalah ruang yang berada di antara otot mylohyoid secara superior, otot platisma inferior, di garis tengah bawah dagu, tepatnya pada daerah segitiga submental yang merupakan bagian dari segitiga anterior leher. ${ }^{5,6}$

Otot pada area ini terdiri dari $4: 1$ ) Mylohyoid muscle superior, 2) Investing layer dari deep cervical fascia inferior (tertutupi oleh platysma muscle), 3) Inferior border dari mandible anterior, 4) Hyoid bone posterior dan 5) Belly anterior dari otot digastrikus lateral (Gambar 6). ${ }^{4,5}$

Area sublingual triangle merupakan area yang mudah dikenali dengan USG. Pada dasar terdapat otot mylohyoid, sympisis mentis dan tulang hyoid. $\mathrm{Di}$ bagian anterior terdapat otot digastrikus. Genioglossus dan geniohyoid ada pada dasar lidah, bersama dengan hyoglossus membentuk muskulus ekstrinsik lidah. Anatomi lainnya yang cukup penting adalah kelenjar sublingual. Kelenjar ini dapat dilihat baik secara transversal ataupun axila. Secara USG kelenjar ini akan terlihat sebagai garis tranversal hypoechoic (Gambar 7,8,9). ${ }^{3,4.5}$

\section{Area Sub Mandibula}

Submandibular triangle terletak pada bagian bawah mandibula dengan batas bawah adalah proseses mastoid dan belly posterior dari otot digastrikus, sedangkan sebelah depan berbatasan dengan belly anterior dari otot digastrikus. Segitiga ini ditutupi oleh fasia superfisial. Platisma, deep

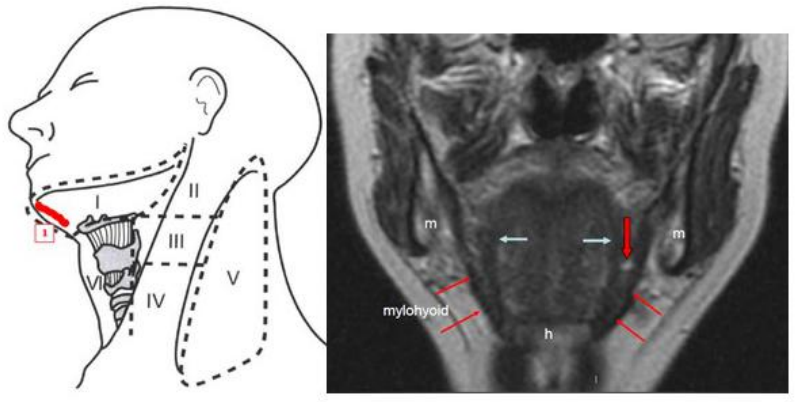

Gambar 7. Terlihat gambaran area submental: tampak otot mylohyoid dari gambaran USG $\mathrm{S}^{3,4,5}$
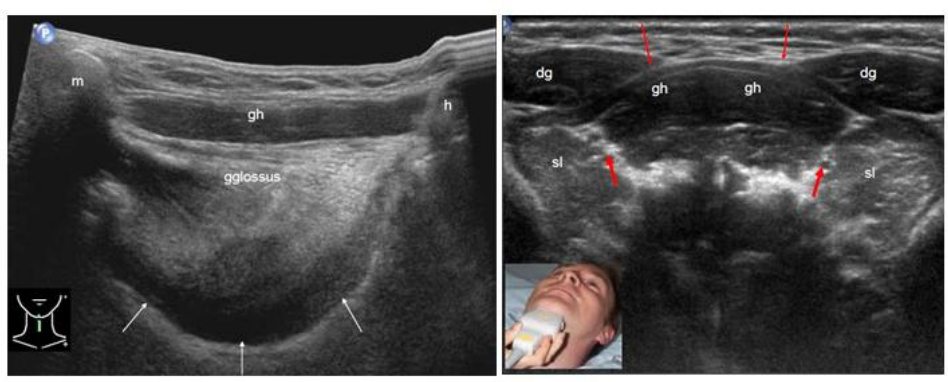

Gambar 8. Beberapa anatomi pada daerah submental ${ }^{3,4}$

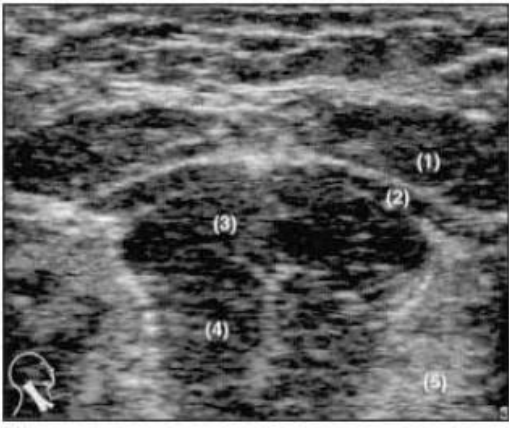

a)

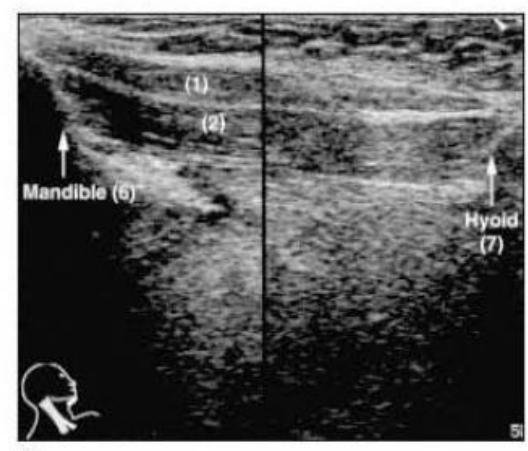

(b)

Gambar 9. Terlihat gambaran (1) Belly anterior dari M digastrikus; (2) Mylohyoid; (3) Geniohyoid; (4) Genioglossus; (5) Kelenjar Sublingual; (6) Mandible; (7) Hyoid. ${ }^{3,4}$ 

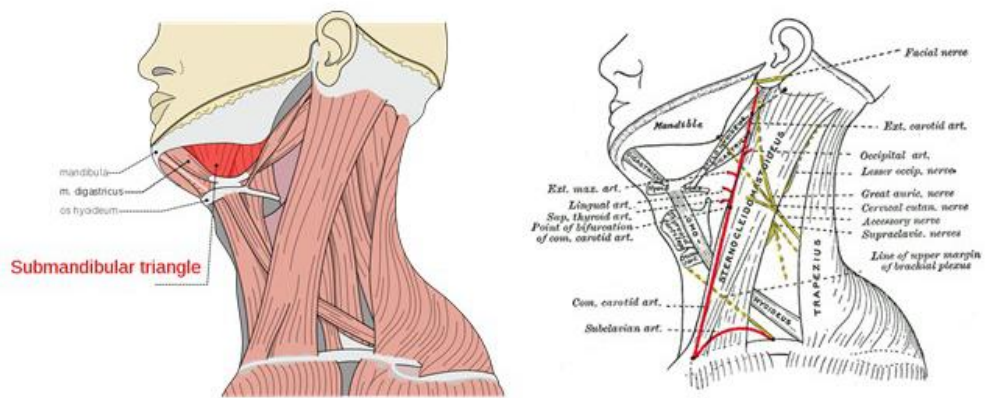

Gambar 10. Bagian anatomi daerah submandibular ${ }^{4,5}$
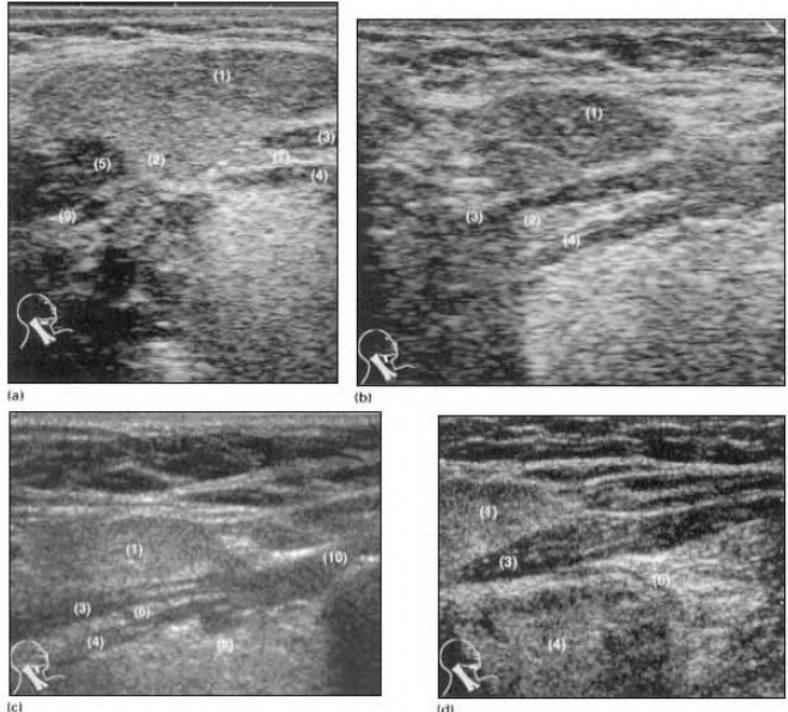

Gambar 11. (a) Potongan transversal, (b) Coronal, (c) Coronal obliq, (d) Transversal dari kelenjar submandibular, dengan anatomi (1) Kelenjar submandibular glans superfisila, (2) Kelenjar submandibular lebih dalam, (3) Mylohyoid, (4) Hyoglossus, (5) Belly posterior digastrikus, (6) Submandibular duct, (7) Vena lingualis, (8) Arteri lingualis, (9) Facial artery, (10) Hyoid bone $3,4,5$

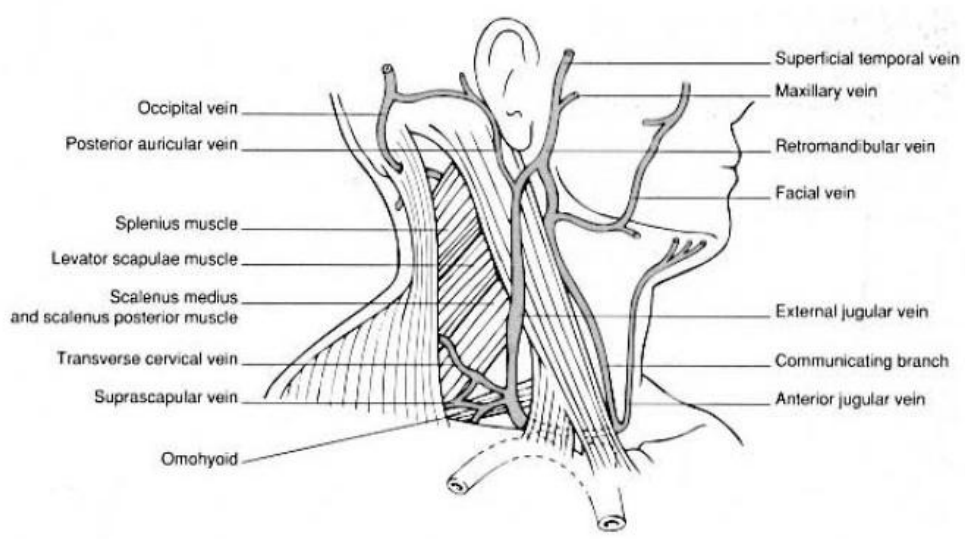

Gambar 12. Terlihat gambaran area dan vaskularisasi dari area parotis ${ }^{5}$

fascia. Otot di bagian dasar M. mylohyoidues anterior posterior hyoglossus. Area Submandibular triangle berbentuk seperti tapak kuda (Gambar $10,11)^{4}$

\section{Area Parotis}

Area parotid adalah area yang merupakan posisi dari kelenjar ludah parotis. Letaknya di daerah depan telinga baik kiri maupun kanan, terbungkus ramus mandibula. ${ }^{5}$ Batasan sebelah anterior terdapat ramus mandibula berbatasan dengan otot maseter dan otot pterygoid medial. Bagian medial berbatasan dengan otot pterygoid medial dan prosesus pterygoid. ${ }^{6}$ Bagian posterior berbatasan dengan prosesus mastoid, tulang temporal, otot sternokleidomastoid, digastrikus, proses styloid serta otot yang melekat pada prosesus ini yaitu stylohyoideus, stylopharyngeus, dan styloglossus. Pada bagian tengah parotis berhubungan dengan otot faringeal superior (Gambar 12, 13). ${ }^{7,8,9}$

\section{Area Cervical}

Area cervikal terdiri dari bagian upper, middle dan lower. Otot yang membentuknya mulai dari otot digastrikus, kelenjar submandibular, otot strenocleidomastoideus, vena jugularis, vena carotis dan otot omohyoid. Bagian upper dan 


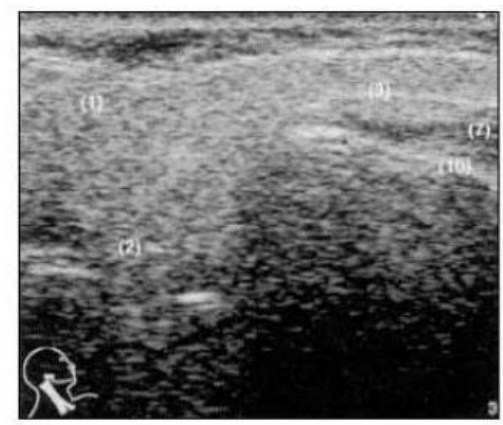

(a)
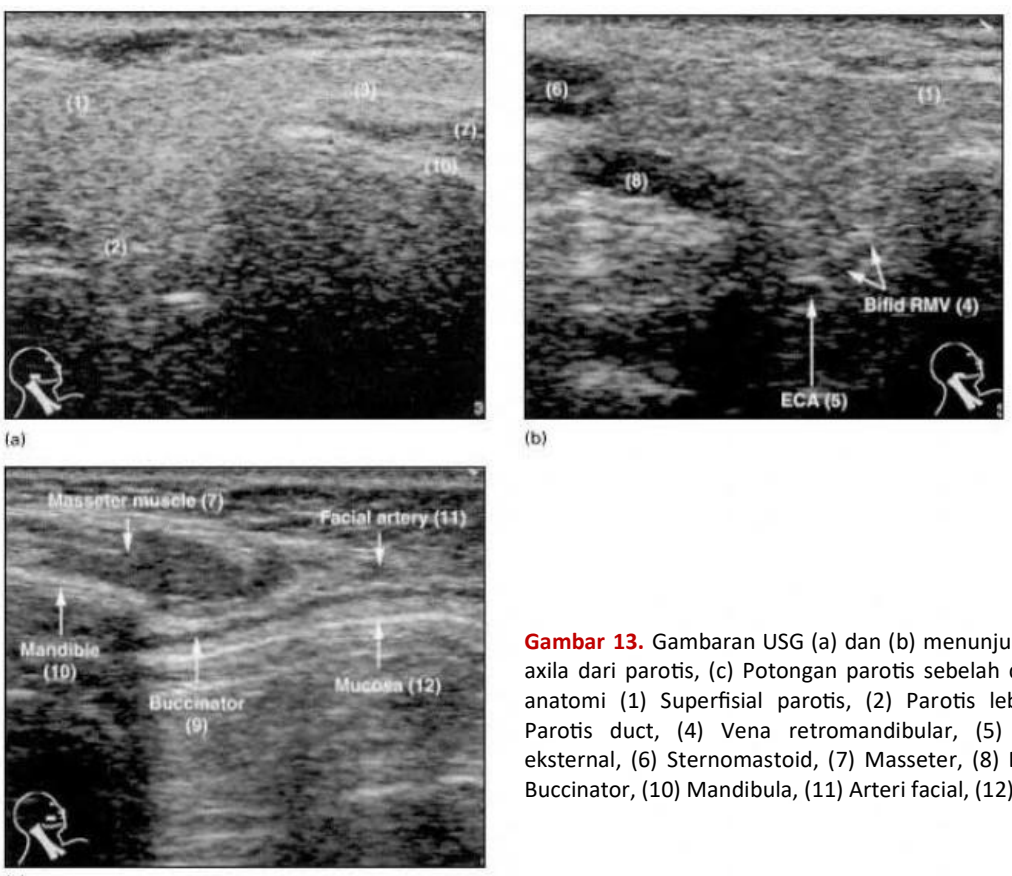

(b)

Gambar 13. Gambaran USG (a) dan (b) menunjukkan potongan axila dari parotis, (c) Potongan parotis sebelah depan. dengan anatomi (1) Superfisial parotis, (2) Parotis lebih dalam, (3) Parotis duct, (4) Vena retromandibular, (5) Arteri carotis eksternal, (6) Sternomastoid, (7) Masseter, (8) Digastrikus, (9) Buccinator, (10) Mandibula, (11) Arteri facial, (12) Mukosa ${ }^{3}$

\section{Peradangan}

Peradangan menyebabkan timbulnya pembengkakan. Pada kondisi seperti ini gambaran akan kehilangan normal echo tekstur atau tampak lower sangat sulit karena lebih banyak tulang permukaannya (Gambar 14,15). 3,9,10,11 $^{2}$

seperti KONDISI PATOLOGIS YANG DAPAT DINILAI seperti gambaran tekstur homogen cerah hampi
MELALUI ULTRASONOGRAFI penelitian membuktikan bahwa sebagian besar peradangan disertai pembengkakan memiliki batas

Kondisi patologis di leher sangat beragam, berikut adalah beberapa kondisi patologis yang dapat dikenali dengan menggunakan USG. yang relatif jelas, intensitas hypoechoic dan memiliki arsitektur homogen. USG dinilai mampu
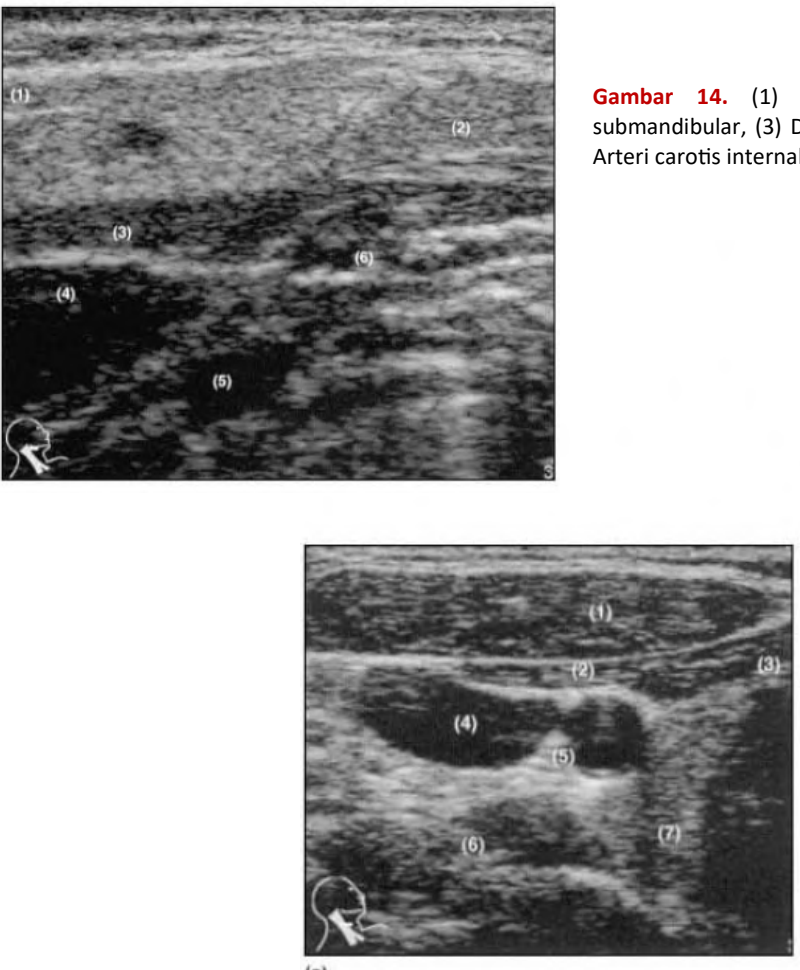

Gambar 15. (1) Sternomastoid, (2) Omohyoid, (3) Strenohyoid, (4) Vena jugular internal, (5) Artery common carotid, (6) Scalenus anterior, (7) Thyroid, (8) Sternomasthyroid, (9) Artery thyroid inferior, (10) Oesophagus ${ }^{3}$
Gambar 14. (1) Kelenjar parotis, (2) Kelenjar submandibular, (3) Digastrikus, (4) Vena jugularis, (5) Arteri carotis internal, (6) Arteri carotis eksternal ${ }^{3}$

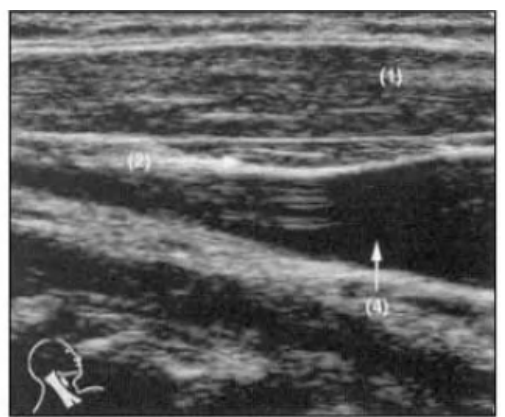

(b)

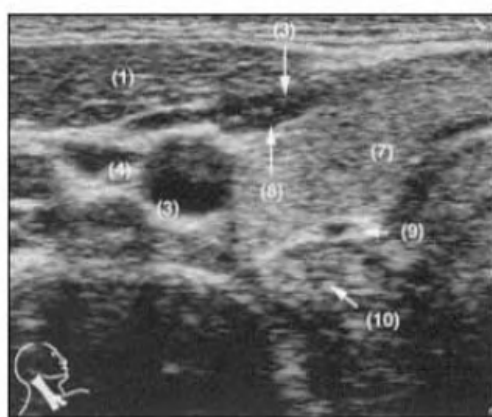




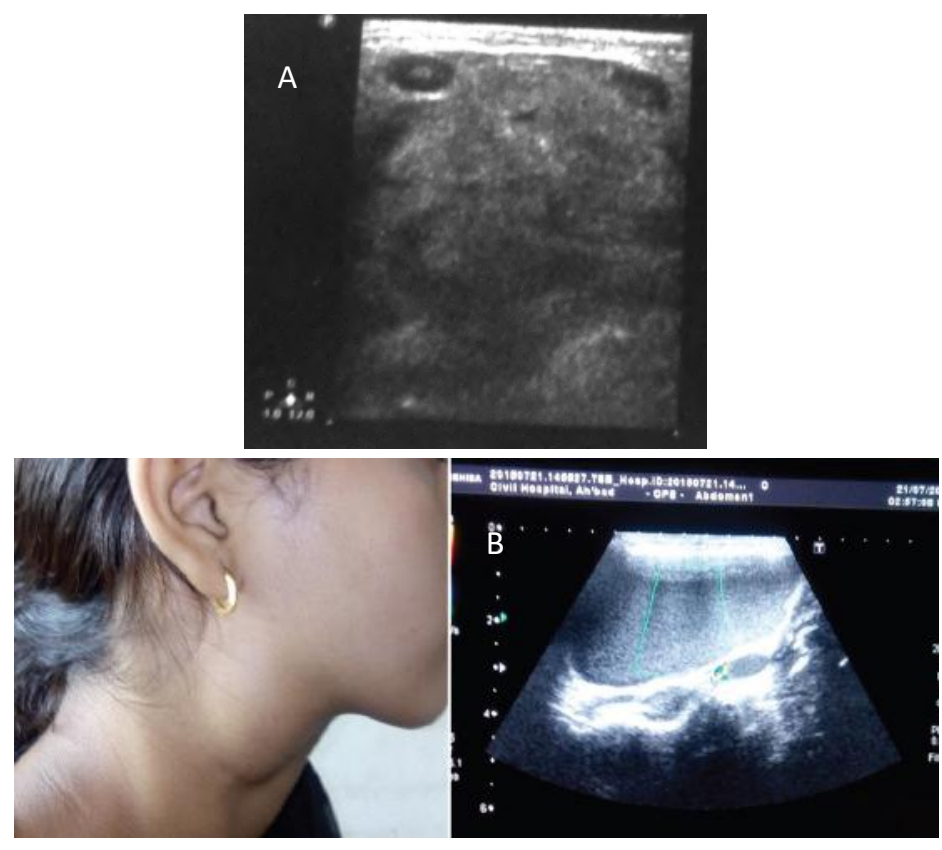

Gambar 16. (A) Gambar dari pasien parotitis, (B) Gambar dari pasien branchial cleft. ${ }^{13}$

melihat sebuah peradangan dengan sensitivitas $97 \%$ dan spesifitas $100 \%$, sedangkan kemampuan dalam mendiagnosis klinis, memiliki sensitivitas dan spesifitas sebesar $85,7 \%$. Hal ini membuktikan bahwa USG cukup memiliki sensitivitas tinggi dalam diagnosis pembengkakan akibat inflamasi pada daerah kepala dan leher. ${ }^{12}$

\section{Tumor}

Tumor jinak kelenjar ludah yang paling umum adalah adenolymphoma, adenoma pleomorfik, sel basal adenoma, myoepithelioma dan sistadenoma papiler. Tumor ganas kelenjar ludah yang paling umum adalah karsinoma mucoepidermoid, karsinoma kistik adenoid, karsinoma sel asin dan adenokarsinoma. ${ }^{12}$ Sebuah massa tumor akan memberikan gambaran intraglandular bersifat hypoechoic jika dibandingkan dengan echogenicity homogen sekitarnya yang normal. Pembengkakan kelenjar pada tumor jinak cenderung berukuran kecil, terdefinisi baik dan tidak terkait dengan nodus serviks yang membesar, sedangkan pada tumor ganas biasanya berbentuk tidak beraturan dan struktur internal yang heterogen. ${ }^{13}$ Gambaran nodus lympatikus pada tumor ganas berbentuk bulat, heterogenitas, arsitektur hilus menghilang, terbentuk pembuluh darah secara abnormal dengan teratur, perubahan kistik dan penyebaran ekstrakapsular. ${ }^{13}$

\section{Kalkulus pada kelenjar ludah}

Penggunaan

mengidentifikasi dan menemukan kalkulus ditemukan pada tahun 1978. USG telah diperkenalkan sebagai teknik pencitraan sederhana dan aman untuk deteksi kalkulus di kelenjar ludah. Batu ludah paling sering terletak di kelenjar submandibular, terdapat sekitar $60-90 \%$ dari semua kasus. $^{14-17}$ Saat ini ultrosonografi dijadikan sebagai metode utama untuk mendeteksi kalkulus saliva karena dapat mencapai sensitivitas $94 \%$ dalam deteksi kalkulus saliva. ${ }^{15}$ Gambaran kalkulus dalam USG memiliki penampilan khas sebagai kompleks hyperechoic lengkung cerah dengan akustik posterior shadow, akan tetapi pada kalkulus yang kecil $(<2 \mathrm{~mm})$, acoustic shadow tidak akan terlihat. ${ }^{16}$ Pada kasus sialolithiasis, sering disertai dengan dilatasi duktus, kejadian ini divisualisasikan sebagai struktur hypoechogenic tubular, sedangkan saluran utama melebar dan memiliki bentuk lebih linier. $^{16}$

\section{SIMPULAN}

USG dapat digunakan untuk mengenal bagian anatomi pada leher dan kepala, dimana pembacaan USG sangat bergantung pada pengetahuan anatomi dari operator yang menggunakannya.

\section{DAFTAR PUSTAKA}

1. Harald Lutz, Elisabetta Buscarini. Manual of diagnostic ultrasound Volume 1, 2nd. WHO Press, Avenue Appia, Geneva, Switzerland; 2011

2. Laurel. Practice Guidline of USG. American Instituide of Ultrasonsography in Medicine. USA; 2014.

3. R M Evans. Practical head and nect Ultrasound. Greenwich. London; 2000

4. Kenneth M. Hargreaves, Stephen Cohen. Cohen's pathways of the pulp.10th. St. Louis, Mosby Elsevier; 2010: 590.

5. Hendry gray. Anatomy of the Human Body. Elsevier English; 2016:502

6. Human Anatomy, Jacobs, Elsevier; 2008: 193

7. Fehrenbach and Herring. Illustrated Anatomy of the Head and Neck. Elsevier; 2012:154

8. Javanshir, K., Amiri, M., Mohseni-Bandpei, M. A., Rezasoltani, A., \& Fernández-de-las-Peñas, C. (2010). Ultrasonography of the Cervical Muscles: A Critical Review of the Literature. Journal of Manipulative and Physiological Therapeutics, 33 (8), 630-637.

Bernard S, Richardson C, Hamann CR, Lee S, Dinh V. Head and Neck Ultrasound Education: A Multimodal Educational 
Approach in the Predoctoral Setting. Ultrasound Med. 2015; 34:1437-1443

10. Gervasio A, Mujahed I, Biasio A, Alessi S. Ultrasound anatomy of the neck: The infrahyoid region. Journal of Ultrasound. 2010; 13(3), 85-89.

11. Rankin G., Stokes M, Newham D.J. Size and shape of the posterior neck muscles measured by ultrasound imaging: normal values in males and females of different ages. Manual Therapy. 2015;10(2):108-115

12. Şehrazat Evirgen, Kıvanç Kamburoğlu. Review on the applications of ultrasonography in dentomaxillofacial region. World J Radiol. 2016. January; 8(1): 50-58

13. Jigna S. Shah, Vijay K. Asrani. Clinical applications of ultrasonography in diagnosing head and neck swellings. Oral Maxillofac Radiol. 2017;5:7-13.

14. Bialek EJ, Jakubowski W, Zajkowski P, Szopinski KT, Osmolsk A. US of the Major Salivary Glands: Anatomy and Spatia Relationships, Pathologic Conditions, and Pitfalls. RadioGraphics. 2006; 26: 745-763.

15. Garcia CJ, Flores PA, Arce JD, Chuaqui B, Schwartz DS Usltrasonography in the study of salivary gland lesions in children. Pediatr Radiol. 1998; 28: 418-425.

16. Gritzmann N, Rettenbacher $T$, Hollerweger A, Macheiner $P$ Hübner E. Sonography of the salivary glands. Eur Radiol. 2003; 13: 964-975

17. Lerena J, Sancho MA, Cáceres F, Krauel L, Parri F, Morales L. Litiasis salival en la infancia. Cir Pediatr. 2007; 20: 101-105 